\title{
Focus on what works and why it works: bridging the gap between research knowledge and practical knowledge
}

\author{
Jan van Tartwijk ${ }^{1}$ (D) $\cdot$ Manon Kluijtmans $^{2}$
}

Published online: 7 June 2017

(C) The Author(s) 2017. This article is an open access publication.

In their contribution to Perspectives on Medical Education, $\mathrm{Ng}$, Baker, and Leslie provide a novel and clear perspective on faculty development in health profession education (HPE) by conceptualizing it as a space for sharing research and practical knowledge [1]. The process of sharing these two types of knowledge implies that both are mobilized during faculty development and, in the end, become related. Successful faculty development then empowers faculty by enriching their contextualized experiential knowledge with research-based knowledge. According to $\mathrm{Ng}$ and colleagues, this enables them to become agents of positive change in their own system.

The key role that teacher involvement plays in the success of educational change has been widely recognized in the literature $[2,3]$. The impact that research knowledge, i. e. evidence generated by systematic empirical research, can have as fuel for innovation of education has also been emphasized [4]. The million-dollar question that still needs to be answered concerns how to close the proverbial gap between research knowledge and practical knowledge [5] within the space professional development provides. Clues for its answer can be found in the literature on teacher professional development.

In an extensive review of the literature on the effectiveness of professional development in HPE, Steinert and her colleagues [6] identify a number of 'key features' that make professional development effective, including the role of ex-

Jan van Tartwijk

j.vantartwijk@uu.nl

1 Department of Education, Faculty of Social and Behavioural Sciences, Utrecht University, Utrecht, The Netherlands

2 Center for Education and Training, University Medical Center Utrecht, Utrecht, The Netherlands periential learning and feedback. They also emphasize the importance of working with peers. Similar reviews in the field of research on teachers and teaching $[7,8]$ found similar features, also emphasizing the importance of a focus on concrete issues related to instruction. Furthermore, models for teacher learning are available that provide suggestions for the utilization of research knowledge in teacher professional development $[9,10]$. In all these models, reflection on application in practice is regarded as a key characteristic of effective professional development. Such reflection should not only focus on what works, but also on why it works, using the knowledge provided by previous research as a starting point.

Here, we want to advocate an approach for faculty development that aims to stimulate faculty to enrich their contextualized experiential knowledge with research-based knowledge, by stimulating them to not only focus on what works, but also on why it works.

Most faculty involved in medical education have been trained as clinicians and many of them also as researchers. Clinicians routinely exert evidence-based practice: integrating scientific evidence with clinical expertise and patient values. As researchers they are familiar with the routine of formulating research questions that are grounded in theory, systematically gathering data for analysis to answer these questions, and reflecting on their findings by considering how these findings match with existing knowledge based on research of others. All of these routines can be used in faculty development. When faculty design education they can use knowledge that is available in the research literature on (medical) education, they can systematically gather data on its success, and they can reflect on their evaluations together with their peers. Many of the key features of effective professional development are included in such approaches, and they could contribute to the development of what is referred 
to in the literature as scholarship of teaching and learning among faculty $[11,12]$. In such a professional development space, research knowledge and practical knowledge would not only be mobilized, but would merge, laying the foundation for education in which research evidence is taken seriously [5].

Of additional importance, faculty might experience a coalescence of clinical, research and teaching roles by taking a scholarly approach to teaching, rather than experiencing teaching as an isolated (or conflicting) task. This could foster a positive narrative on teaching, which might strengthen teacher identity and motivation [13].

Conflict of interest J. van Tartwijk and M. Kluijtmans declare that they have no competing interests.

Open Access This article is distributed under the terms of the Creative Commons Attribution 4.0 International License (http:// creativecommons.org/licenses/by/4.0/), which permits unrestricted use, distribution, and reproduction in any medium, provided you give appropriate credit to the original author(s) and the source, provide a link to the Creative Commons license, and indicate if changes were made.

\section{References}

1. Ng SL, Baker LR, Leslie K. Re-positioning faculty development as knowledge mobilization for health professions education. Perspect Med Educ. 2017. doi:10.1007/s40037-017-0362-0.

2. Kelly B. Key themes and future directions for implementation science and psychology in education. In: Kelly B, Perkins DF, editors. Handbook of implementation sciencefor psychology in education. New York: Cambridge University Press; 2012. pp. 461-4.

3. Fullan M. The new meaning of educational change, 4th ed. New York: Teachers College; 2007.

4. Slavin RE. Evidence-based education policies: transforming educational practice and research. Educ Res. 2002;31:15-21.
5. van der Vleuten CPM, Driessen EW. What would happen to education if we take education evidence seriously? Perspect Med Educ. 2014;3:222-32.

6. Steinert Y, Mann K, Centeno A, et al. A systematic review of faculty development initiatives designed to improve teaching effectiveness in medical education: BEME Guide No. 8. Med Teach. 2006;28:497-526.

7. van Driel J, Meirink J, Van Veen K, Zwart R. Current trends and missing links in studies on teacher professional development in science education: a review of design features and quality of research. Stud Sci Educ. 2012;48:129-60.

8. Desimone LM, Porter AC, Garet MS, Yoon KS, Birman BF. Effects of professional development on teachers' instruction: results from a three-year longitudinal study. Educ Eval Policy Anal. 2002;24:81-112.

9. Clarke D, Hollingsworth H. Elaborating a model of teacher professional growth. Teach Teach Educ. 2002;18:947-67.

10. Korthagen FAJ, Kessels J, Koster B, Lagerwerf B, Wubbels T. Linking practice and theory: the pedagogy of realistic teacher education. Mahwah: Lawrence Erlbaum; 2001.

11. Mårtensson K, Roxå T, Olsson T. Developing a quality culture through the scholarship of teaching and learning. High Educ Res Dev. 2011;30:51-62.

12. Trigwell K, Shale S. Student learning and the scholarship of university teaching. Stud High Educ. 2004;29:523-36.

13. van Lankveld T, Schoonenboom J, Kusurkar RA, Volman M, Beishuizen J, Croiset G. Integrating the teaching role into one's identity: a qualitative study of beginning undergraduate medical teachers. Adv Health Sci Educ. 2016; doi:10.1007/s10459-0169694-5.

Jan van Tartwijk $\mathrm{PhD}$, is a professor of Education at Utrecht University. He is the chair of Utrecht University's Graduate School of Teaching and the scientific manager of the educational development and training group (O\&T) of the faculty of Social and Behavioural Sciences.

Manon Kluijtmans $\mathrm{PhD}$, is an associate professor at the University Medical Center Utrecht. She is the education director of the Utrecht University's master in Clinical Health Sciences which includes Physiotherapy Science, Nursing Science and Clinical Speech and language Sciences, as well as a premasters program Clinical Health Sciences. 